\title{
Geochemical Assessment of Trace Metals in Peri-Urban Drainage and Bioaccumulation in Selected Food Crops in the Kumasi Metropolis, Ghana
}

\author{
Gordon Foli ${ }^{1}$, Simon K. Y. Gawu ${ }^{1}$, Blestmond A. Brako ${ }^{1} \&$ Prosper M. Nude ${ }^{2}$ \\ ${ }^{1}$ Geological Engineering Department, Kwame Nkrumah University of Science and Technology, Kumasi, Ghana \\ ${ }^{2}$ Department of Earth Sciences, University of Ghana, Legon-Accra, Ghana \\ Correspondence: Gordon Foli, Geological Engineering Department, Kwame Nkrumah University of Science and \\ Technology (KNUST), Kumasi, Ghana. Tel: 233-20-813-4579. E-mail: gordon.foli01@gmail.com; \\ gfoli.coe.knust.edu.gh
}

Received: December 5, 2018

Accepted: December 20, 2018

Online Published: January 4, 2019

doi:10.5539/enrr.v9n1p25

URL: https://doi.org/10.5539/enrr.v9n1p25

\begin{abstract}
This paper evaluates some geochemical properties of trace metals in peri-urban drainage and bioaccumulation in cassava, plantain, lettuce and sugarcane in the Kumasi metropolis in Ghana, West Africa. The aim is to establish water quality and food safety. Water, sediment and the food crops were sampled along the profiles of Wiwi and Subin rivers for analysis. T-test statistic shows that $\mathrm{pH}, \mathrm{HCO}_{3}, \mathrm{Cl}, \mathrm{Cu}, \mathrm{As}, \mathrm{Pb}$ and $\mathrm{Ni}$ are significant in water and sediment. Mean concentrations of $\mathrm{Cu}, \mathrm{As}, \mathrm{Pb}$ and $\mathrm{Ni}$ in water and sediment are $(0.01 \mathrm{mg} / \mathrm{l} ; 3.2 \mathrm{mg} / \mathrm{kg}),(3.08 \mathrm{mg} / \mathrm{l}$; $4.9 \mathrm{mg} / \mathrm{kg}),(0.034 \mathrm{mg} / 1 ; 8.7 \mathrm{mg} / \mathrm{kg})$ and $(0.021 \mathrm{mg} / 1 ; 6.1 \mathrm{mg} / \mathrm{kg})$, respectively. In water, $\mathrm{As}, \mathrm{Pb}$ and $\mathrm{Ni}$ concentrations are above primary maximum contamination limits of $0.05 \mathrm{mg} / 1,0.015 \mathrm{mg} / \mathrm{l}$ and $0.020 \mathrm{mg} / \mathrm{l}$ with metal ratios of 61.54, 2.27 and 1.05, respectively. In sediment, As concentration is above the continental crustal background value of $1.8 \mathrm{mg} / \mathrm{kg}$ with a metal ratio of 2.72. From geochemical process models: (1) As and Ni adsorbs into sediment and may lead to attenuation in water in closed systems; (2) $\mathrm{Cu}$ and $\mathrm{Pd}$ are in equilibrium and may affect water quality at higher concentrations. The food crops have trace metals concentrations below reference values and bioaccumulation factors $<1$. The food crops are therefore excluders, and safe for dietary intake. Members in cassava-plantain-lettuce and cassava-lettuce-sugarcane suites have translocation factors (TFs) $>1$ for $\mathrm{Cu}$ and As, respectively, while lettuce has $\mathrm{TF}>1$ for $\mathrm{Pd}$ and Ni. Crops with $\mathrm{TF}>1$ may bioaccumulate the respective trace metals in over a prolonged period.
\end{abstract}

Keywords: Bioaccumulate, Translocation, Subin, Wiwi, Excluders, Sediment, Water, Attenuation

\section{Introduction}

Pollutants in soils are becoming higher by the day due to increasing anthropogenesis (Taghipour, Mosaferi, Armanfar, \& Gaemmagami, 2013). Weathering of rocks often mobilizes elements which, when exposed to agents of erosion are transported and re-distributed in the environment (Khirbash \& Semhi, 2015). Trace elements distribution in soils depends on the nature of parent material, weathering processes, human activity and climatic conditions (Rezapour, Golmohammad, \& Ramezanpour, 2014; Huot, Simonnot, \& Morel, 2015). Metals such as As, $\mathrm{Pd}$ and $\mathrm{Cd}$ can be highly toxic and exhibit complex behaviours and can enter the food chain; exposure of the elevated levels of trace metals in the environment can pose threat to health and life (Xie, Peng, Wang, \& Chen, 2017; Hu, Jia, Hu, Xu, Xia, \& Li, 2017).

According to Lago-Vila, Arenas-Lago, Andrade and Vega (2014), the availability of metal contents in soil depends on the availability of water, metals present and soil properties. The characteristics of the metals are controlled by the drainage chemistry of the ecosystems, which serves as sinks for the pollutants and constitute ecological risks (Wuana \& Okieimen, 2011). The bioavailable fractions of the contaminants present in the ecosystem or geo-matrix provide indicators for risk-based regulatory guidelines for the improvement of food safety (Lago-Vila et al., 2014). Contaminant refers to elements in the available fraction of soils that relates to the concentration of elements in soil solutions and the capacity of transfer from the solid phase (Lago-Vila et al., 2014).

Rapid urbanization in the Kumasi metropolis in Ghana has led to the increased generation of waste and trace metals distribution in geo-hydrologic media (Ahmed \& Dinye, 2012; Amoateng, Cobbinah, \& Owusu-Adade, 2013). As 
noted by Serfes, Spayd and Herman (2005) and O'Shea, Stransky, Leitheiser, Brock, Marvinney and Zheng (2015), trace metals distribution may also be attributed to regional geologic processes, as well as the influx of seasonal metal-laden fine dust from the Sahel region (He, Breuning-Madsen, \& Awadzi, 2007). Vehicular movement on feeder roads in the metropolis and rainfall run-offs may contribute trace metals distribution.

An assessment of $\mathrm{Pb}, \mathrm{Cu}, \mathrm{Zn}, \mathrm{Ni}$, and $\mathrm{Cd}$ in soils and common food crops such as cassava and plantain was conducted within a small-scale gold-mining environment in the Wassa-Amenfi-West District of Ghana (Zango, Anim-Gyampo, \& Ampadu, 2013). Results show the metal concentrations in the soil samples were within the permissible limits of EU standards even though Pollution Load Index indicated significant metal loading. $\mathrm{Pb}, \mathrm{Cd}$, $\mathrm{Zn}$ and $\mathrm{Cu}$ contents in food crops were higher than in soils and exceeded FAO/WHO recommended values for plantain and cassava and pose long-term health conditions from dietary intake (Zango et al., 2013).

The Kumasi metropolis has a history of annual flooding, which results in the replenishment of overbank sediments with plant nutrients and trace metals. Pollution studies in the metropolis by Keraita, Drechsel and Amoah (2003) focussed on the impacts of biological parameters in drainage. Also, Boateng, Opoku, Acquaah and Akoto (2015) show that well-water from the Ejisu-Juaben area has trace elements pollution concerns. Amonoo-Neizer and Amekor (1993) evaluated Total As in soils, water and biological samples in the Kumasi area and published a range from 0.07 to $7.20 \mathrm{mg} / \mathrm{kg}$. All these pieces of research, however, did not highlight mechanisms of the behaviours of the parameters.

A process model to explain the mobility of trace metals in drainage using a relevant conservative tracer is described in Berger, Bethke, and Krumhansl (2000) and Svensson, Lovett and Likens (2012). The model uses the influence of external water, mixing with background water to express the geochemical behaviour of elements (Berger et al., 2000). Chloride ( $\mathrm{Cl}$ ) is commonly used as a conservative tracer because of its low mobility (Svensson et al., 2012). The mobility of $\mathrm{Cl}$ is mainly dependent on physical conditions, rather than chemical processes, unless it is present in very high concentrations (Snyder, 2011).

In situations where $\mathrm{Cl}$ is too low, an available copiously mobilised anion such as $\mathrm{SO}_{4}$ may be used as the conservative tracer (Berger et al., 2000) to avoid turning out erroneous interpretations due to low $\mathrm{Cl}$ contents (Svensson et al., 2012). Berger et al. (2000) plotted metal contents against the $\mathrm{SO}_{4}$ and deduced mixing lines by linking the two extremes of the paired data points. Plot values above a mixing line indicate addition of metal ion species to solution through mineral dissolution/desorption while the converse implies the removal from the drainage. Foli, Gawu and Nude (2015) used $\mathrm{SO}_{4}$ as a conservative tracer in the Obuasi mine environment in Ghana and noted that $\mathrm{Fe}$ and $\mathrm{As}$ were desorbed into the drainage.

Food crops such as cassava and plantain, together with fruits and vegetables, traditionally serve as food or dietary energy input for humans in sub-Saharan Africa (Chen, Huang, Lai, \& Chen, 2015). In the research area, cassava, plantain, sugar cane and cabbage are highly patronised by communities within the catchment of the rivers, where they are grown on both commercial and subsistence basis in areas influenced by overbank sediment or irrigated by water from the drainage systems.

This study evaluated (1) geochemical characteristics of some trace metals in peri-urban drainage; (2) bioaccumulation status of the trace metals in the selected food crops that grow in the drainage environment. The aim was to ensure water quality and food safety in related environments.

\section{Methods}

\subsection{The Study Area}

The study area is located at the extreme north end of the Paleoproterozoic Kumasi basin between the grid limits of $6.5997^{\circ} \mathrm{N}-6.7068^{\circ} \mathrm{N}$ and $1.5148^{\circ} \mathrm{W}-1.76237^{\circ} \mathrm{W}$ and covers a land surface area of about $144 \mathrm{~km}^{2}$. Vegetation is of the semi-equatorial type with annual average temperature and rainfall of about $28^{\circ} \mathrm{C}$ and $1,340 \mathrm{~mm}$, respectively. Drainage pattern is relatively dense and dendritic (Keraita et al., 2015), with flow patterns having a general direction of North-South at the rate of some $0.243 \mathrm{~m}^{3} \mathrm{~s}^{-1}$ (Ahmed \& Dinye, 2012).

The underlying geology consists of the Paleoproterozoic Birimian metasedimentary rocks, within about an $80 \mathrm{~km}$ wide anticlinal basin and intruded by granite-granodiorite suites (Chudasama, Porwal, Kreuzer, \& Butera, 2015). The basin is dissected by a $10-20 \mathrm{~km}$ wide NE-SW trending shear systems permeated by hydrothermal fluid flow and gold mineralisation (Chudasama et al., 2015), with associated sulphide minerals dominated by arsenopyrite and pyrite (Oberthur, Vetter, Mumm, Weiser, Amanor, Gyapong, Kumi, \& Blenkinsop, 1994). The sulphide minerals decompose to release trace metals such as copper $(\mathrm{Cu})$, arsenic $(\mathrm{As})$, lead $(\mathrm{Pb})$, nickel $(\mathrm{Ni})$ and zinc $(\mathrm{Zn})$ into soils (Foli \& Gawu, 2017, 2018). Auriferous sediments overly the bedrocks and constitute sources of extensive small-scale mining activities (Buadee, Gawu, \& Foli, 2018). 


\subsection{Water and Sediment Sampling}

Water and overbank sediment samples were taken from 18 sampling sites (SP), 9 each along the profiles of the Wiwi and Subin rivers as presented in Figure 1.

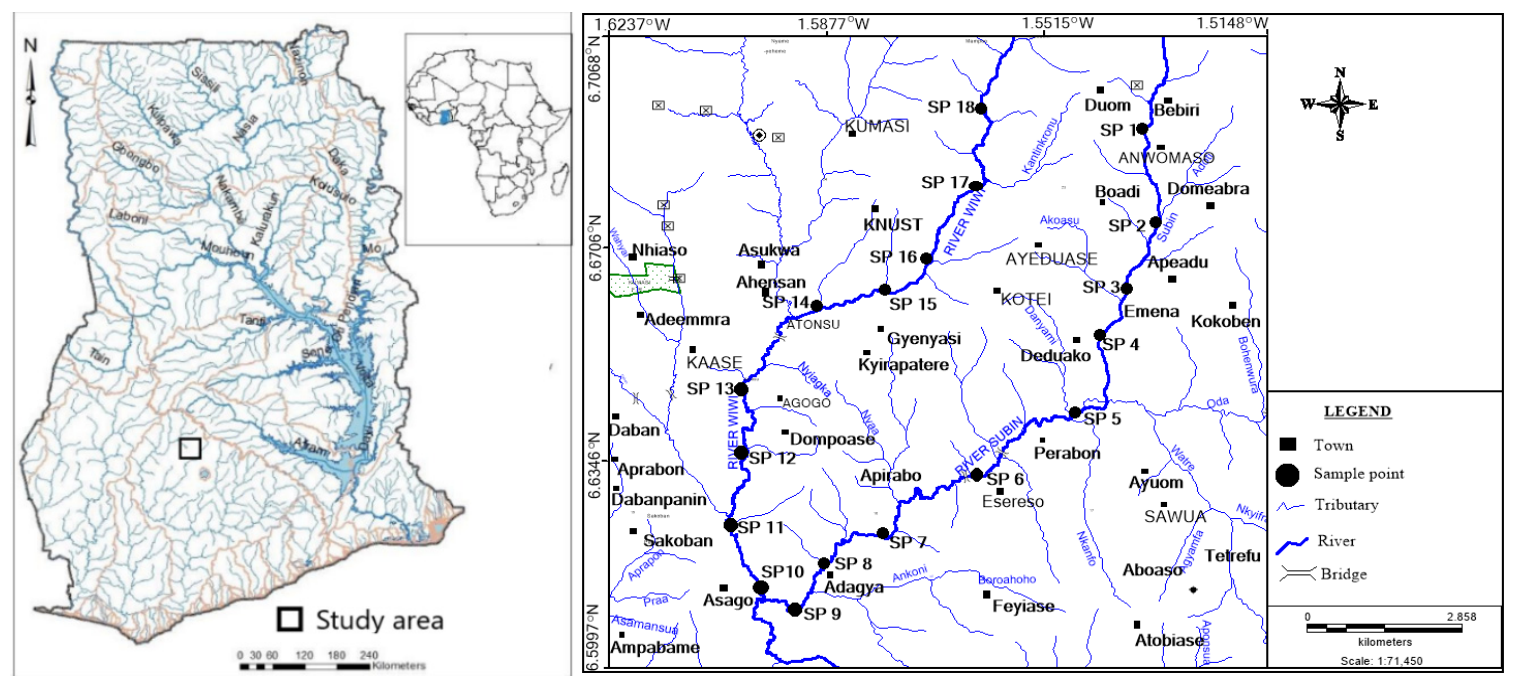

Figure 1. A Sketch map showing study area, water and sediment sample locations

About 500ml-sized clean plastic bottles were used for the water sampling, while about $500 \mathrm{~g}$ of sediment samples were taken with a clean plastic trowel. Water samples were filtered with cellulose nitrate membrane filters of pore size $0.45 \mu \mathrm{m}$ using vacuum filtration. The filtrates were analysed for $\mathrm{pH}$, bicarbonate $\left(\mathrm{HCO}_{3}\right)$, chloride $(\mathrm{Cl})$, sulphate $\left(\mathrm{SO}_{4}\right)$ and nitrate $\left(\mathrm{NO}_{3}\right)$. Filtrates were acidified using concentrated $\mathrm{HNO}_{3}$ at $\mathrm{pH} 2$ for trace metals determination.

Split portions of the sediment samples were oven-dried $90^{\circ} \mathrm{C}$ overnight and digested in aqua regia composed of a mixture of $11.5 \mathrm{~N} \mathrm{HCl}$ and $15.5 \mathrm{~N} \mathrm{HNO}_{3}$ at $90-100^{\circ} \mathrm{C}$ for 1 hour and allowed to stand for 30 minutes. Decanted sample solutions were, filtered and used for the analyses of elements such as copper $(\mathrm{Cu})$, arsenic $(\mathrm{As})$, lead $(\mathrm{Pb})$, nickel (Ni) and zinc $(\mathrm{Zn}) .100 \mathrm{ml}$ of distilled water was added to $200 \mathrm{~g}$ of the other split samples and prepared for the determination of $\mathrm{pH}$ and the anions. Details can be found in Eppinger, Briggs, Rosenkrans and Ballestrazze (1999) and also in a summarised form in Foli and Nude (2012).

\subsection{Water and Sediment Sampling}

Root and shoot samples of cassava, lettuce, plantain and sugar cane were sampled from three different sites. The samples were washed with distilled water and oven-dried at $60^{\circ} \mathrm{C}$ to attain a constant weight. The samples were crushed and 2 grams of each sample was digested over a period of 30-60 minutes in a Kjeldahl tube using perchloric, nitric acid and hydrochloric acid in the ratio of $1: 2: 3$ at a temperature of $450^{\circ} \mathrm{C}$ (Nagornyy, 2013). The mixtures were decanted into volumetric flasks and topped-up to the $100 \mathrm{ml}$ mark for trace metals analyses.

\subsection{Analytical Procedures}

The Corning $\mathrm{pH} / \mathrm{C} 107$ meter was used to measure $\mathrm{pH}$ values, while anions were analysed using ion chromatography (IC) at a detection limit of $0.01 \mathrm{mg} / \mathrm{l}$ (APHA, 1999). Dilute $\mathrm{HCl}$ was prepared to desk reagent standards and then standardised against $40 \mathrm{ml} 0.05 \mathrm{~N} \mathrm{Na}_{2} \mathrm{CO}_{3}$ using $\mathrm{pH}$ meter as an indicator, and used for the titration to determine alkalinity (APHA, 1999). The metals were determined using the ICP-OES at a detection limit of $0.0002 \mathrm{mg} / 1$ (e.g. Hou \& Jones, 2000).

Field-split duplicates were used to estimate analytical precision. Standard solutions containing $10.0 \mathrm{mg} / \mathrm{l}$ for specific analytes were spiked by adding equal volumes of known concentrations determined at selected sites. The spiking results fall within the acceptable limits of $\pm 10 \%$ when compared with the expected (e.g. Foli \& Nude, 2012).

\subsection{Metal Ratios and Geochemical Process Modelling}

The metal ratio (MR) of the trace metals in the environment can be expressed as: 


$$
\mathrm{MR}=\frac{\text { Concentration of the element in sample }}{\text { Background concentration of element }}
$$

Equation (1)

The MR is interpreted as Low if $\mathrm{MR}<1$; moderate for the range 1-3; considerable for 3-6; and very high for MR $\geqslant 6$ (e.g. Olatunji, Abimbola, \& Afolabi, 2009). The primary maximum contamination levels $\left(1^{\circ} \mathrm{MCL}\right)$ in water and continental crust values for the parameters in sediment are taken from Wilson and Salomon (2002) and Windom (1988), respectively. Binary plots of the trace metals and $\mathrm{Cl}$ concentrations in water were generated and the extreme paired data points linked to define a mixing line for determining of the metal availability (Berger et al., 2000; Svensson et al., 2012).

\subsection{Translocation and Bioaccumulation Factors}

Plant-soil relationships were assessed for trace metal accumulation in the plants as translocation factor (TF):

$$
\mathrm{TF}=\frac{\text { Concentration of the element in shoot }}{\text { concentration of the element in root }}
$$

$\mathrm{TF}>1$ indicates that the plants translocate metals effectively from the root to the shoot (Baker \& Brooks, 1989). The higher the TF value, the higher the mobility or availability of the element. Bioaccumulation factor (BF) is defined as

$$
\mathrm{BF}=\frac{\text { Concentration of the element in plant }}{\text { concentration of the element in sediment }}
$$

$\mathrm{BF}>1$ indicates that the plant accumulates, while $<1$ implies that the plant is an excluder (Mganga, Manoko, \& Rulangaranga, 2011). Similar as TF, the higher the BF value, the higher the availability of the element in the plant that can be taken up the food chain.

\section{Results and Discussions}

\subsection{Parameter Distributions in Water and Sediment Samples}

Parameter values were assessed for p-values at 95\% confidence level (CL) using the Anderson-Darling test criteria

\begin{tabular}{|c|c|c|c|c|c|c|c|c|c|c|}
\hline S. No. & $\mathrm{pH}$ & $\mathrm{HCO}_{3}$ & $\mathrm{Cl}$ & $\mathrm{SO}_{4}$ & $\mathrm{NO}_{3}$ & $\mathrm{Cu}$ & As & $\mathrm{Pb}$ & $\mathrm{Ni}$ & $\mathrm{Zn}$ \\
\hline 1 & 6.6 & 32 & 1.11 & 6.0 & 1.3 & 0.005 & 2.428 & 0.024 & 0.012 & 0.004 \\
\hline 2 & 6.8 & 31 & 1.14 & 6.0 & 1.0 & 0.005 & 2.904 & 0.024 & 0.011 & 0.003 \\
\hline 3 & 6.9 & 19 & 0.42 & 6.0 & 1.1 & 0.008 & 2.952 & 0.025 & 0.016 & 0.005 \\
\hline 4 & 7.0 & 20 & 0.45 & 7.0 & 1.2 & 0.005 & 2.857 & 0.032 & 0.011 & 0.004 \\
\hline 5 & 7.1 & 33 & 0.46 & 7.0 & 1.4 & 0.006 & 2.743 & 0.024 & 0.011 & 0.003 \\
\hline 6 & 7.1 & 29 & 0.81 & 6.0 & 1.2 & 0.006 & 2.381 & 0.028 & 0.023 & 0.003 \\
\hline 7 & 7.1 & 38 & 0.89 & 9.0 & 1.3 & 0.005 & 2.351 & 0.029 & 0.016 & 0.005 \\
\hline 8 & 7.2 & 36 & 0.84 & 9.0 & 1.1 & 0.012 & 2.842 & 0.033 & 0.009 & 0.004 \\
\hline 9 & 7.3 & 33 & 0.88 & 8.0 & 1.9 & 0.015 & 2.402 & 0.033 & 0.008 & 0.003 \\
\hline 10 & 6.9 & 44 & 1.13 & 6.4 & 1.4 & 0.009 & 3.423 & 0.041 & 0.021 & 0.005 \\
\hline 11 & 6.8 & 52 & 1.13 & 6.0 & 1.1 & 0.007 & 4.343 & 0.041 & 0.028 & 0.004 \\
\hline 12 & 6.9 & 29 & 0.73 & 6.0 & 1.1 & 0.009 & 2.753 & 0.038 & 0.022 & 0.003 \\
\hline 13 & 6.1 & 31 & 0.74 & 6.0 & 1.7 & 0.020 & 4.011 & 0.044 & 0.046 & 0.005 \\
\hline 14 & 6.8 & 32 & 1.47 & 9.0 & 1.5 & 0.010 & 3.548 & 0.042 & 0.031 & 0.004 \\
\hline 15 & 6.7 & 41 & 1.47 & 9.0 & 1.3 & 0.017 & 3.743 & 0.04 & 0.044 & 0.004 \\
\hline 16 & 6.7 & 39 & 1.22 & 9.5 & 1.1 & 0.012 & 3.088 & 0.036 & 0.016 & 0.004 \\
\hline 17 & 6.9 & 46 & 1.26 & 9.0 & 1.8 & 0.012 & 3.412 & 0.041 & 0.031 & 0.005 \\
\hline 18 & 6.7 & 28 & 0.98 & 9.0 & 1.8 & 0.018 & 3.204 & 0.032 & 0.021 & 0.004 \\
\hline Mean & 6.9 & 34 & 0.95 & 7.4 & 1.4 & 0.010 & 3.077 & 0.034 & 0.021 & 0.004 \\
\hline $\mathrm{p}$-values & 0.187 & 0.502 & 0.574 & $<0.005$ & 0.024 & 0.077 & 0.406 & 0.145 & 0.059 & $<0.005$ \\
\hline
\end{tabular}
in the Minitab release 14 software are listed in Tables 1 and 2.

Table 1. Parameter concentrations in water samples

Inorganic parameters are in $\mathrm{mg} / \mathrm{kg}$, while $\mathrm{pH}$ is quantified in values 
Table 2. Parameter concentrations in sediment samples

\begin{tabular}{lllllllllll}
\hline S. No. & $\mathrm{pH}$ & $\mathrm{HCO}_{3}$ & $\mathrm{Cl}$ & $\mathrm{SO}_{4}$ & $\mathrm{NO}_{3}$ & $\mathrm{Cu}$ & $\mathrm{As}$ & $\mathrm{Pb}$ & $\mathrm{Ni}$ & $\mathrm{Zn}$ \\
\hline 1 & 5.9 & 44.0 & 1.2 & 11 & 4.6 & 2.1 & 4.7 & 4.5 & 7.8 & 1.9 \\
2 & 5.9 & 39.0 & 1.1 & 11 & 5.2 & 1.5 & 5.1 & 5.8 & 7.6 & 2.0 \\
3 & 5.6 & 65.0 & 2.3 & 12 & 3.3 & 2.2 & 4.2 & 4.2 & 5.4 & 2.0 \\
4 & 5.8 & 71.0 & 2.1 & 15 & 3.9 & 4.7 & 5.0 & 4.3 & 5.5 & 1.8 \\
5 & 5.5 & 55.0 & 2.2 & 14 & 5.2 & 2.9 & 4.2 & 50 & 7.9 & 1.9 \\
6 & 6.0 & 37.0 & 1.8 & 18 & 2.8 & 2.1 & 4.3 & 5.7 & 7.7 & 1.3 \\
7 & 5.5 & 41.0 & 2.4 & 20 & 2.7 & 2.7 & 4.8 & 4.5 & 6.3 & 1.7 \\
8 & 5.7 & 62.0 & 2.1 & 13 & 2.9 & 3.6 & 4.8 & 5.8 & 4.8 & 1.4 \\
9 & 5.8 & 66.0 & 3.1 & 15 & 3.1 & 2.5 & 4.7 & 3.9 & 6.8 & 1.4 \\
10 & 7.2 & 55.0 & 3.6 & 18 & 5.3 & 4.5 & 5.1 & 6.2 & 5.0 & 1.4 \\
11 & 6.6 & 78.0 & 3.8 & 14 & 5.5 & 2.5 & 4.4 & 6.9 & 4.3 & 1.5 \\
12 & 6.5 & 63.0 & 3.5 & 10 & 5.2 & 3.1 & 5.4 & 7.2 & 5.2 & 1.5 \\
13 & 6.3 & 61.0 & 3.4 & 12 & 4.4 & 3.0 & 5.6 & 7.1 & 5.5 & 1.4 \\
14 & 6.6 & 44.0 & 3.2 & 19 & 3.6 & 5.3 & 5.2 & 7.8 & 5.2 & 1.9 \\
15 & 6.4 & 57.0 & 2.5 & 20 & 2.9 & 3.8 & 6.2 & 8.0 & 6.6 & 1.7 \\
16 & 6.6 & 42.0 & 3.2 & 15 & 3.1 & 5.5 & 5.5 & 9.4 & 6.4 & 1.7 \\
17 & 6.5 & 48.0 & 2.7 & 12 & 2.8 & 3.5 & 4.3 & 6.3 & 5.1 & 1.5 \\
18 & 6.3 & 53.0 & 3.7 & 12 & 2.7 & 2.8 & 4.5 & 9.0 & 6.6 & 1.8 \\
Mean & 6.2 & 55 & 2.7 & 15 & 3.8 & 3.2 & 4.9 & 8.7 & 6.1 & 1.7 \\
p-values & 0.250 & 0.603 & 0.352 & 0.081 & 0.005 & 0.225 & 0.531 & 0.572 & 0.134 & 0.076 \\
\hline
\end{tabular}

Inorganic parameters are in $\mathrm{mg} / \mathrm{kg}$, while $\mathrm{pH}$ is quantified in values

In Tables 1 and 2, $\mathrm{pH}$ values and concentrations in both media for $\mathrm{CO}_{3}, \mathrm{Cl}, \mathrm{Cu}, \mathrm{As}, \mathrm{Pb}$ and $\mathrm{Ni}$ are significant at $\mathrm{p}$ values $>0.05$ while $\mathrm{NO}_{3}, \mathrm{SO}_{4}$ and $\mathrm{Zn}$ are insignificant at $\mathrm{p}$-values $<0.05$. The mean values of the significant parameters in both water and sediment, respectively, are $\mathrm{pH}(6.9 ; 6.2), \mathrm{HCO}_{3}(34.0 \mathrm{mg} / 1 ; 55.0 \mathrm{mg} / \mathrm{kg}), \mathrm{Cl}(0.95 \mathrm{mg} / 1$; $2.7 \mathrm{mg} / \mathrm{kg}), \mathrm{Cu}(0.01 \mathrm{mg} / 1 ; 3.2 \mathrm{mg} / \mathrm{kg})$, As $(3.08 \mathrm{mg} / 1 ; 4.9 \mathrm{mg} / \mathrm{kg}), \mathrm{Pb}(0.034 \mathrm{mg} / 1 ; 8.7 \mathrm{mg} / \mathrm{kg})$ and Ni $(0.021 \mathrm{mg} / 1 ;$ $6.1 \mathrm{mg} / \mathrm{kg}$ ).

The concentrations of $\mathrm{As}, \mathrm{Pb}$ and $\mathrm{Ni}$ in water are above the $1^{\circ} \mathrm{MCL}$ values of $0.05 \mathrm{mg} / 1,0.015 \mathrm{mg} / 1$ and $0.020 \mathrm{mg} / 1$, respectively, while $\mathrm{Cu}$ is below the $1^{\circ} \mathrm{MCL}$ value of $1.3 \mathrm{mg} / \mathrm{l}$. In sediment, $\mathrm{Cu}, \mathrm{Pb}$ and $\mathrm{Ni}$ concentrations are below continental crust background values of $55 \mathrm{mg} / \mathrm{kg}, 12.5 \mathrm{mg} / \mathrm{kg}$ and $75 \mathrm{mg} / \mathrm{kg}$, respectively. The As concentration in this study is thus above the continental crustal background value of $1.8 \mathrm{mg} / \mathrm{kg}$ and can mobilise in the environment.

The near-neutral mean $\mathrm{pH}$ of 6.9 in water probably for accounted for the low concentrations of $\mathrm{Cu}, \mathrm{Pb}$ and $\mathrm{Ni}$ in water, but responsible for the mobilisation of As in the water (e.g. Appelo \& Postma, 2005; Foli \& Nude, 2012). The dominance of As in the environment may be due to redistribution of elements from mineralised zones associated with deep-seated shear zones flanking the Paleo-Proterozoic Kumasi basin (Chudasama et al., 2015).

Trace metals distribution can be attributed to regional geologic processes such as hydrothermal fluid flow through shear zones (Serfes et al., 2005; O'shea et al., 2015). From these sources, the elements may have migrated by geohydrologic processes within the sub-surface into environmental receptors such as streams, rivers, overbank sediments and soils. The low $\mathrm{Cl}$ levels in the environment may be explained by the fact that $\mathrm{Cl}$ concentrations are very low in in-situ materials. Svensson et al. (2012) noted that $\mathrm{Cl}$ has low mobility that is mainly dependent on physical conditions, rather than chemical processes; as such, most rocks release very little of the element into drainage (Snyder, 2011).

\subsection{Trace Metals Enrichment in Water and Sediment}

From equation (1), the metal ratios in both water and sediment are presented in Figure 2. 

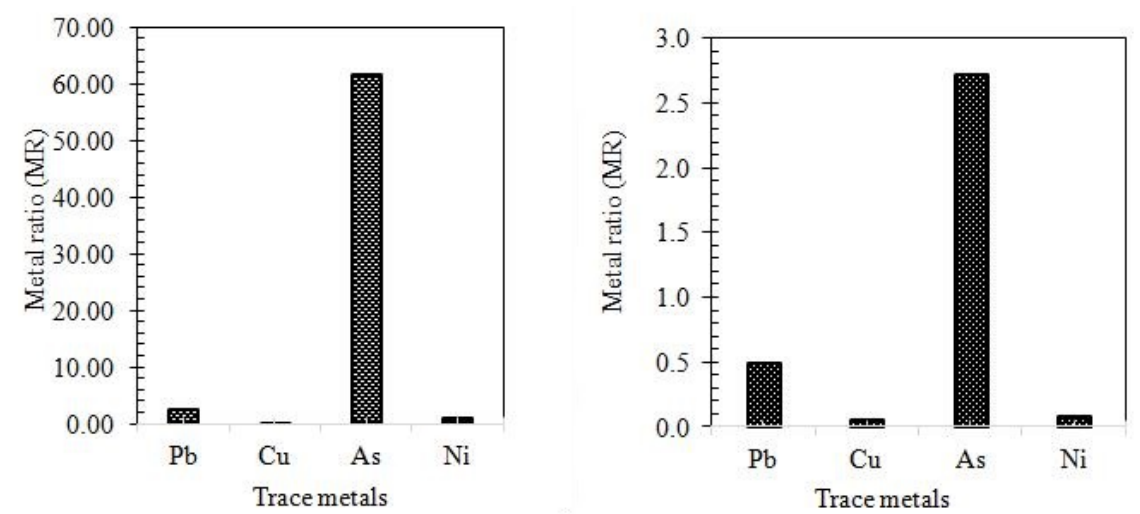

Figure 2. Metal ratios in water (left) and sediment (right)

In Figure 2 (left), the metal ratio (MR) of 61.60 for As indicates very high contamination in the water, while the $\mathrm{MR}$ for $\mathrm{Pb}$ and $\mathrm{Ni}$ as 2.3 and 1.05 indicates moderate contaminations. $\mathrm{MR}<1$ for $\mathrm{Cu}$ imply that the water is lowly contaminated with the metal. In Figure 3(b), As has MR of 2.7, which represents moderate contamination in the sediment, while $\mathrm{MR}<1$ for $\mathrm{Pb}, \mathrm{Cu}$ and $\mathrm{Ni}$ indicates that the sediment is lowly contaminated with the metals. The order of contamination of the metals in both media is generalised as $\mathrm{As}>\mathrm{Pb}>\mathrm{Ni}>\mathrm{Cu}$. Clearly, $\mathrm{As}, \mathrm{Pb}$ and $\mathrm{Ni}$ are of health concern in water for direct consumption since the MR $>1$. The availability of the element in the aqueous state was estimated from the geochemical process models using $\mathrm{Cl}$ as a conservative tracer.

\subsection{Geochemical Process Model of Trace Metals in Water}

From the geochemical model plots for the metals, data points above the mixing line indicate the addition of ions to the drainage, either from mineral dissolution/desorption. Conversely, data points below the mixing line indicate removal of ions from the drainage through mineral precipitation/adsorption. Equal distribution of data points about the mixing line signifies equilibrium between the two scenarios stated above. The model plots are presented in Figure 3 .
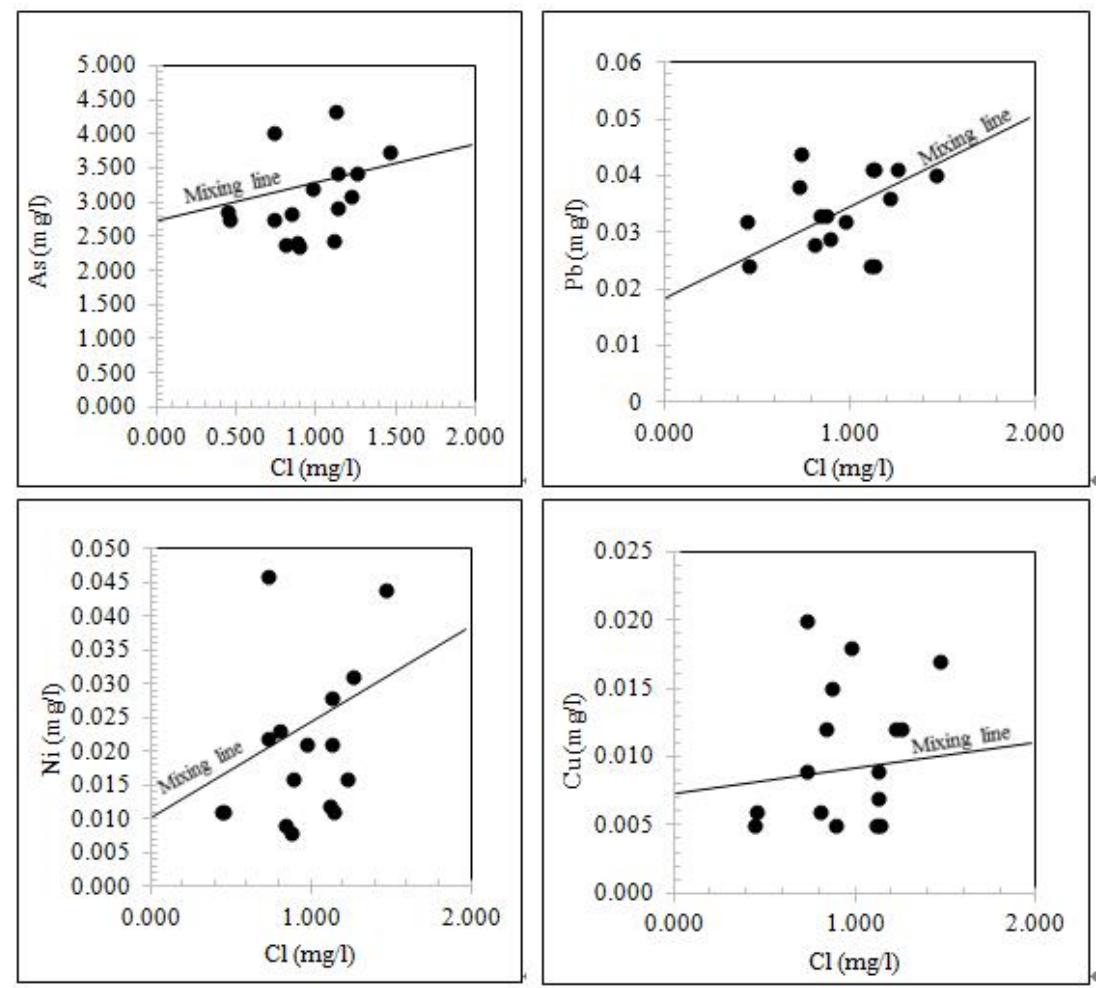

Figure 3. Process model plots for the significant trace metals using $\mathrm{Cl}$ as the conservative tracer 
From Figure 3, the data point distribution about the mixing line and the stability interpretations of As, Pd, Ni and $\mathrm{Cu}$ are established and presented in Table 3.

Table 3. Interpretation of trace metals behaviours in drainage

\begin{tabular}{llll}
\hline Metal & Data points above mixing line & Data points below mixing line & Process \\
\hline $\mathrm{Pb}$ & $50 \%$ & $50 \%$ & Equilibrium \\
$\mathrm{Cu}$ & $50 \%$ & $50 \%$ & Equilibrium \\
$\mathrm{As}$ & $31.25 \%$ & $68.75 \%$ & Adsorption \\
$\mathrm{Ni}$ & $37.5 \%$ & $62.5 \%$ & Adsorption \\
\hline
\end{tabular}

From Table 3, $\mathrm{Pb}$ and $\mathrm{Cu}$ are at equilibrium in both media, while As and $\mathrm{Ni}$ are adsorbing from water into the sediment. The implications are that $\mathrm{Cu}$ and $\mathrm{Pb}$ are likely to have a high residence time in the aqueous state and therefore have the potential for plants uptake, when there is an increase in concentration, whereas As and Ni would attenuate with time under closed conditions.

\subsection{Bioaccumulation of Trace Metals in Food Crops}

Mean concentrations of the trace metals in soils, roots, shoots and plant (root and shoot) are compared with references for safe consumption (Kabata-Pendias, 2011) as shown in Table 4.

Table 4. Bioaccumulation data for selected food crops

\begin{tabular}{|c|c|c|c|c|c|c|}
\hline \multirow{2}{*}{ Metal } & Soils & \multirow{2}{*}{ Sample } & Cassava & Lettuce & Plantain & Sugar cane \\
\hline & $\mathrm{mg} / \mathrm{kg}$ dry wt. & & \multicolumn{4}{|c|}{$\mathrm{mg} / \mathrm{kg}$ dry wt. } \\
\hline \multirow{4}{*}{$\mathrm{Cu}$} & \multirow{4}{*}{3.2} & Root & 0.70 & 0.65 & 0.78 & 0.57 \\
\hline & & Shoot & 0.74 & 0.68 & 0.84 & 0.52 \\
\hline & & Plant & 0.72 & 0.67 & 0.81 & 0.55 \\
\hline & & Reference & $3-6$ & $6-8$ & $1.1-2$ & 73.30 \\
\hline \multirow{4}{*}{ As } & \multirow{4}{*}{4.9} & Root & 0.016 & 0.015 & 0.020 & 0.010 \\
\hline & & Shoot & 0.021 & 0.016 & 0.018 & 0.020 \\
\hline & & Plant & 0.189 & 0.016 & 0.019 & 0.015 \\
\hline & & Reference & $10-20$ & $20-50$ & NA & $0.5-62$ \\
\hline \multirow{4}{*}{$\mathrm{Pb}$} & \multirow{4}{*}{6.2} & Root & 0.006 & 0.003 & 0.025 & 0.030 \\
\hline & & Shoot & 0.005 & 0.007 & 0.020 & 0.011 \\
\hline & & Plant & 0.006 & 0.005 & 0.023 & 0.021 \\
\hline & & Reference & $0.5-3$ & $0.7-3.6$ & 0.30 & $111-186$ \\
\hline \multirow{4}{*}{$\mathrm{Ni}$} & \multirow{4}{*}{6.1} & Root & 0.065 & 0.065 & 0.087 & 0.080 \\
\hline & & Shoot & 0.045 & 0.075 & 0.049 & 0.078 \\
\hline & & Plant & 0.055 & 0.070 & 0.068 & 0.079 \\
\hline & & Reference & $0.29-1.0$ & $0.6-3.3$ & 67.90 & $10-24$ \\
\hline
\end{tabular}

From Table 4, the mean concentrations of all the four trace metals in the crops are below the reference concentrations published in Kabata-Pendias (2011). The results show that the toxicity levels for dietary intake of the crops are low and therefore pose no risk for consumers. From the shoot, root and soil concentrations, translocation and bioaccumulation factors were estimated using equations 2 and 3 to establish the mobility and availability of the metals in the food crops as represented in Figure 4. 


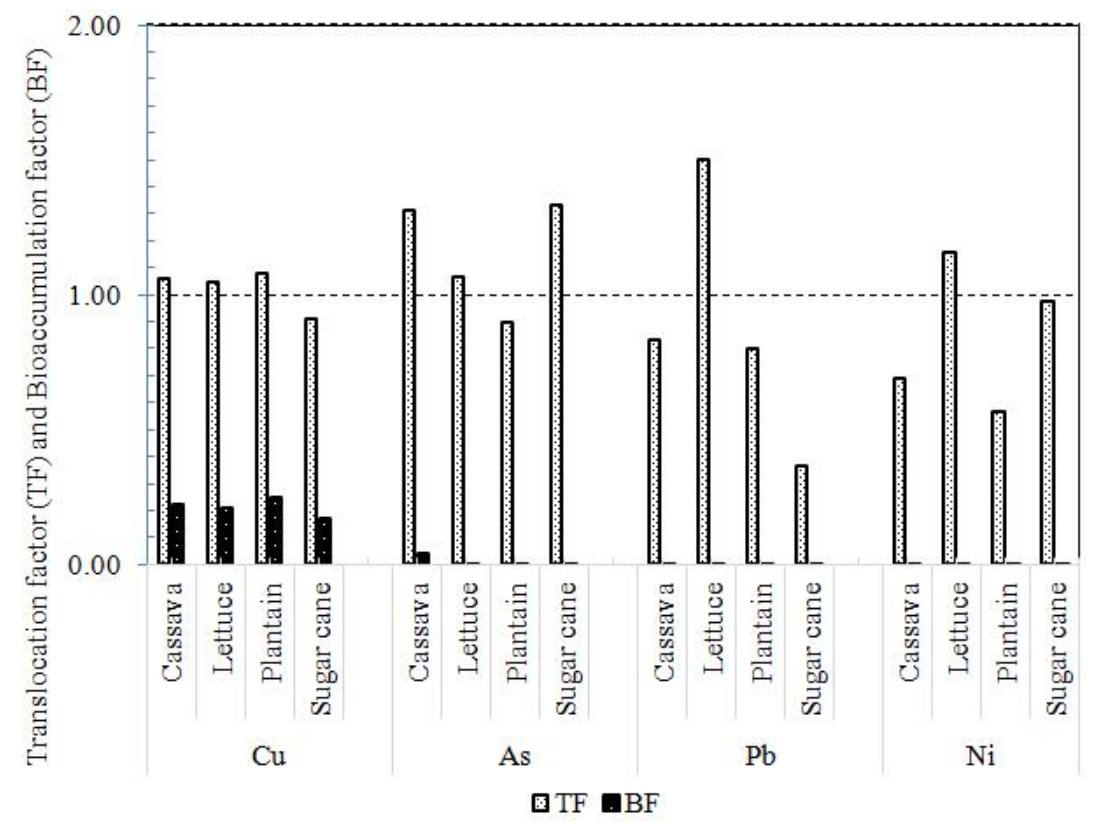

Metals (mg/kg dry wt.)

Figure 4. Chart for Translocation and Bioaccumulation Factors of the elements in the food crops

From Figure 4, cassava, lettuce and plantain have $\mathrm{TR}>1$ for $\mathrm{Cu}$; cassava, lettuce and sugarcane have $\mathrm{TF}>1$ for As, while plantain and lettuce have $\mathrm{TF}>1$ for both $\mathrm{Pb}$ and $\mathrm{Ni}$. This indicates that the listed plants can translocate the respective metals effectively from the root to shoot. All the food crops have $\mathrm{BF}<1$ for all the trace metals and are therefore excluders in the current state. That notwithstanding, food crops having TR $>1$ are likely to bioaccumulate the respective trace metals when left too long in the field. Overall, $\mathrm{Cu}$ shows the highest tendency of bioaccumulation in the food crops with a significant average $\mathrm{BF}$ value of 0.20 .

\section{Conclusions and Recommendation}

The order of contamination of the trace metals in both media is $\mathrm{As}>\mathrm{Pb}>\mathrm{Ni}>\mathrm{Cu}$. Under the current environmental conditions, $\mathrm{As}, \mathrm{Pb}$ and $\mathrm{Ni}$ concentrations are above $1^{\circ} \mathrm{MCL}$ values for drinking water. From geochemical process models, As and $\mathrm{Ni}$ would attenuate in water over time in closed systems, while $\mathrm{Cu}$ and $\mathrm{Pd}$ are in equilibrium may affect water quality at higher concentrations. The toxicity levels for dietary intake of the food crops are very low and pose no risk for consumers in the current state. All the food crops have bioaccumulation factor (BF) $<1$ for the trace metals and can, therefore, be considered as excluders under the current conditions. Food crops having translocation factor (TR) $>1$ for whichever trace metal(s), may bioaccumulate the respective trace metal(s) in the food crop(s) over a prolonged period of growth. It is recommended that the use of the untreated water for direct consumption be avoided to prevent direct intake of high concentrations of $\mathrm{As}, \mathrm{Pb}$ and $\mathrm{Ni}$. Food crops, grown within the overbank sediments, floodplains or where the water from the rivers is used for irrigation purposes should not be left to overgrow in the field before harvesting.

\section{Conflict of interests}

The authors declare that there is no conflict of interests regarding the publication of this paper.

\section{References}

Ahmed, A., \& Dinye, R. D. (2012). Impact of land use activities on Subin and Aboabo Rivers in Kumasi Metropolis. International Journal of Water Resources and Environmental Engineering, 4(7), 241-251.

Amoateng, P., Cobbinah, P. B., \& Owusu-Adade, K. (2013). Managing Physical Development in Peri-Urban areas of Kumasi, Ghana: A Case of Abuakwa. Journal of Urban and Environmental Engineering, 7(1), 96-109.

Amonoo-Neizer, E. H., \& Amekor, E. M. K. (1993) Determination of Total Arsenic in Environmental Samples from Kumasi and Obuasi, Ghana. Environmental Health Perspectives, 101(1), 46-49. 
APHA. (1999). Standard Methods for the Examination of Water and Wastewater: (C Copyright 1999 by APHA, American Water Works Association. Water Environment Federation, 8. Retrieved July 20, 2014 from http://folk.uio.no/rvogt/KJM_MEF_4010/

Appelo, C. A. J., \& Postma, D. (2005). Geochemistry, Groundwater and Pollution (2nd ed., p. 536). Balkema, Netherlands.

Baker, A. J. M., \& Brooks, R. R. (1989). Terrestrial higher plants which hyperaccumulate metallic Elements-A review of their distribution, ecology and phytochemistry. Biorecovery, 1, 81-126.

Berger, A. C., Bethke, C. M., \& Krumhansl, J. L. (2000). A process model of natural attenuation in drainage from a historic mining district. Applied Geochemistry, 15, 655-666.

Boateng, T. K., Opoku, F., Acquaah, S. O., \& Akoto, O. (2015). Pollution evaluation, sources and risk assessment of heavy metals in hand-dug wells from Ejisu-Juaben Municipality, Ghana. Environmental Systems Research, $4(18)$.

Buadee, N. A., Gawu, S. K. Y., \& Foli, G. (2018). Assessing the Occupational Risks associated with Artisanal and Small-Scale mining-A Case study in Asankrangwa and Kenyasi Areas in Ghana. West African Journal of Applied Ecology, 26(1), 22-32.

Chen, T., Huang, L., Lai, G., \& Chen, G. (2015). Inorganic arsenic in starchy roots, tubers, and plantain and assessment of cancer risk of sub-Saharan African populations. Food Control, 53, 104-108

Chudasama, B., Porwal, A., Kreuzer, O. P., \& Butera, K. (2015). Geology, geodynamics and orogenic gold prospectivity modelling of the Paleoproterozoic Kumasi Basin, Ghana, West Africa. Ore Geology Review.

Eppinger, R. G., Briggs, P. H., Rosenkrans, D., \& Ballestrazze, V. (2000). Environmental Geochemical Studies of Selected Mineral Deposits in Wrangell- St. Elias Alaska National Park and Preserve, Alaska. Retrieved November 25, 2016 from http://greenwood.cr.usgs.gov/pub/../p1619

Foli, G., \& Gawu, S. K. Y. (2017). Modified Acid-base Accounting Model Validation and pH Buffer Trend Characterisation in Mine Drainage at the AngloGold-Ashanti Obuasi mine in Ghana, West Africa. Environ. Earth Sci., 76(19), 663.

Foli, G., \& Gawu, S. K. Y. (2018). Using an integrated method for the determination of environmental TCLP arsenic for sulphide-rich mine tailing remediation in Ghana, West Africa. Environ. Earth Sci., 77, 1-11.

Foli, G., \& Nude, P. M. (2012). Concentration levels of some Inorganic contaminants in streams and sediments in areas of pyrometallurgical and hydrometallurgical activities at the Obuasi mine, Ghana. Environ. Earth Sci., $65,753-763$.

Foli, G., Gawu, S. K. Y., \& Nude, P. M. (2015). Arsenic contamination and secondary mineral evaluation in mine drainage using integrated acid-base accounting and toxicity characterisation leaching procedure: The case of Obuasi Mine, Ghana. Environ. Earth Sci., 73, 8471-8486.

He, C., Breuning-Madsen, H., \& Awadzi, T. W. (2007). Mineralogy of dust deposited during the Harmattan season in Ghana. Danish Journal of Geography, 107(1), 9-15.

Hou, X., \& Jones, B. T. (2000). In R. A. Meyers (Ed.), Encyclopedia of Analytical Chemistry (pp. 9468-9485). John Wiley \& Sons Ltd, Chichester.

Hu, B., Jia, X., Hu, J., Xu, D., Xia, F., \& Li, Y. (2015). Assessment of Heavy Metal Pollution and Health Risks in the Soil-Plant-Human System in the Yangtze River Delta, China. International Journal of Environmental Research and Public Health, 14, 1042.

Huot, H., Simonnot, M. O., \& Morel, J. L. (2015). Pedogenetic Trends in Soils Formed in Technogenic Parent Materials. Soil Science, Lippincott, Williams Wilkins, 80(4/5), 182-192.

Kabata-Pendias, A. (2011). Trace Elements in Soils and Plants (4th ed.). CRC Press, Boca Raton, Florida.

Keraita, B., Drechsel, P., \& Amoah, P. (2003). Influence of urban wastewater on stream water quality and agriculture in \& around Kumasi, Ghana. Environment and Urbanization, 15, 171.

Khirbash, S. A., \& Semhi, K. (2015). Mobilization and Redistribution of Elements in Laterites of Semail Ophiolite, Oman: A Mass Balance Study. SQU Journal for Science, 20(1), 39-54.

Lago-Vila, M., Arenas-Lago, D., Andrade, L., \& Vega, F. A. (2014). Phytoavailable content of metals in soils from copper mine tailings (Touro mine, Galicia, Spain). Journal of Geochemical Exploration, 147, 159-166. 
Mganga, N., Manoko, M. L. K., \& Rulangaranga, Z. K. (2011). Classification of Plants According to their Heavy Metal Content around North Mara Gold Mine, Tanzania: Implication for Phytoremediation. Tanzanian Journal of Science, 37, 11.

Nagornyy, V. D. (2013). Soil and Plant Laboratory Analysis (Textbook) (p. 144). УДК 631/635(075.8):632.08(07): ББК 28.081.2+28.581.2.

Nude, P. M., Foli, G., \& Yidana, M. (2011). Geochemical assessment of the impact of mine spoils on the quality of stream sediments within the Obuasi mines environment, Ghana. International Journal of Geosciences, 2, 259-266.

Oberthur, T., Vetter, U., Mumm, A. S., Weiser, Th., ..., \& Blenkinsop, T. G. (1994). The Ashanti gold mine at Obuasi, Ghana: Mineralogical, Geochemical, Stable isotope and Fluid inclusion studies on the metallogenesis of the Deposit. Geologisches Jahrbuch, 100, 31-129.

Olatunji, A. S., Abimbola, A. F., \& Afolabi, O. O. (2009). Geochemical Assessment of Industrial Activities on the Quality of Sediments and Soils within the Lsdpc Industrial Estate, Odogunyan, Lagos, Nigeria. Global Journal of Environ. Research, 3(3), 252-257.

O'Shea, B., Stransky, M., Leitheiser, S., Brock, P., Marvinney, R. G., \& Zheng, Y. (2015). Heterogeneous arsenic enrichment in meta-sedimentary rocks in central Maine, United States. Science of the Total Environment, 505(1), 1308-1319.

Rezapour, S., Golmohammad, H., \& Ramezanpour, H. (2014). Impact of parent rock and topography aspect on the distribution of soil trace metals in natural ecosystems. Int. J. Environ. Sci. Technol., 11, 2075-2086.

Serfes, M. E., Spayd, S. E., \& Herman, G. C. (2005). Arsenic Occurrence, Sources, Mobilization, and Transport in Groundwater in the Newark Basin of New Jersey Advances in Arsenic Research. American Chemical Society, 915, 175-190.

Snyder, G. (2011). Chloride in Water: School Science Fair Water 101. Retrieved November 23, 2016 from $\mathrm{http} / /$ sciencefairwater.com/chemical-water-quality-parameters/primary-anions-and-cations/chloride/...

Svensson, T., Lovett, G. M., \& Likens, G. E. (2012). Is chloride a conservative ion in Forest Ecosystems? Biogeochemistry, 107(1-3), 125-134.

Taghipour, H., Mosaferi, M., Armanfar, F., \& Gaemmagami, S. J. (2013). Heavy metals pollution in the soils of Suburban areas in big cities: A case study. Int. J. Environ. Sci. Technol., 10, 243-250.

Wilson, E., \& Solomon, C. (2002). Metals Limits: Current Drinking Water Standards, EPA Office of Water. Retrieved January 3, 2012 from http://www.occ.state.ok.us/divisions/og/

Windom, H. L. (1988). In S. J. Schropp (Ed.), A guide to the interpretation of metal concentrations in estuarine Sediments. Regulation 2600 Blairstone Rd. Tallahassee, Florida: FL 32399-3000.

Wuana, R. A., \& Okieimen, F. E. (2011). Heavy Metals in Contaminated Soils: A Review of Sources, Chemistry, Risks and Best Available Strategies for Remediation. International Scholarly Research Network ISRN Ecology, 2011, 20.

Xie, W., Peng, C., Wang, H., \& Chen, W. (2017). Health Risk Assessment of Trace Metals in Various Environmental Media, Crops and Human Hair from a Mining Affected Area. International Journal of Environmental Research and Public Health. Retrieved November 19, 2018 from https://www.ncbi.nlm.nih.gov/pmc/articles/PMC5751012/

Zango, M. S., Anim-Gyampo, M., \& Ampadu, B. (2013). Health Risks of Heavy Metals in selected Food Crops cultivated in Small-scale Gold-mining Areas in Wassa-Amenfi-West District of Ghana. Journal of Natural Sciences Research, 3(5), 96-105.

\section{Copyrights}

Copyright for this article is retained by the author(s), with first publication rights granted to the journal.

This is an open-access article distributed under the terms and conditions of the Creative Commons Attribution license (http://creativecommons.org/licenses/by/4.0/). 